\title{
Deltagende overvågning og sociale fællesskaber på nettet
}

\section{Anders Albrechtslund}

Artiklen handler om de forskelligartede overvågningspraksisser, der er opstået i forbindelse med nye sociale medier. Fokus er sarligt på den måde overvågning indgår som et boerende element $i$ den sociale interaktion, hvor brugerne deler informationer med et netvoerk.

Nøgleord: overvågning, sociale medier, deltagelse, magt

\section{English summary: Participatory surveillance and online social networking}

The article is about the different surveillance practices that have appeared in the wake of new social media. Focus is on how surveillance is a central part of social interaction, as users share information with a network.

Keywords: surveillance, social media, participation, empowerment

\section{Indledning}

I denne artikel sætter jeg fokus på en type overvågning, der er særlig genkendelig i forbindelse med sociale fællesskaber på nettet. ${ }^{1}$ Her viser det sig, at overvågning er en grundlæggende praksis i de sociale interaktioner (at se og blive set). Anskuet på den måde løsrives overvågningen ikke blot fra forestillingen om en uhyggelig storebror (Orwells 1984) eller som et fængslende, disciplinerende blik (Benthams panoptikon) og tænkes i stedet for ind i en mere positiv og opbyggelig sammenhæng. Artiklens ambition er derfor dels at bidrage til en pluralistisk forståelse, der ser med andre øjne på den teoretiske diskussion af overvågningspraksisser og -teknologier, og dels 
at præsentere en ramme, som kan bidrage til bedre forståelse af begrebet deltagelse, der sammen med synlighed, magt og gensidighed er centrale i forbindelse med sociale fællesskaber på nettet.

I det følgende afsnit præsenterer jeg kort de oftest benyttede overvågningsbegreber og nogle af de vigtigste kendetegn ved sociale fællesskaber på nettet, som oplæg til en diskussion af sikkerheds- og privatlivsproblemstillinger, der ofte fremhæves i forbindelse med det sociale liv på nettet. Herefter introducerer jeg begrebet deltagende overvågning som et alternativt perspektiv på social interaktion. Formålet er her at bidrage til bedre at kunne forstå de grunde og hensigter, som mennesker kan have til at tage del i deres egen overvågning - en praksis, der ikke kan forklares fra et orwelliansk, panoptisk eller andet velkendt overvågningsperspektiv.

\section{Overvågningsbegreber}

Vores forståelse af overvågning er stærkt præget af fiktionens verden. Her vil jeg især fremhæve George Orwells 1984 (1949), der langt hen ad vejen har udstyret os med forestillinger og begreber, som har været flittigt brugt i den offentlige debat. Også inden for forskningen i overvågning har den famøse Big Brother spillet en afgørende rolle for teoriudviklingen, ligesom andre begreber fra denne romans univers har været taget $\mathrm{i}$ brug som forståelsesramme. Udover Orwells bog har Jeremy Benthams fængselsskitser fra slutningen af det attende århundrede om et «panoptikon» haft stor indflydelse på moderne teorier om overvågning. I en samling breve udgivet i 1791 fremlagde Bentham sin ide om et bygningsværk, der skulle muliggøre effektivt opsyn og kontrol. Ordet panoptikon er en nydannelse af de græske ord «pan» (alt) og «optikos» (vedrørende synet) og betyder noget i retning af «det altseende sted», for det karakteristiske ved en panoptisk bygning er, at der fra ét bestemt sted er overblik over hele bygningen. Bentham er en central skikkelse indenfor utilitarismen, og denne tankegangs økonomiske maksimeringsprincip kan spores i den panoptiske bygning. Her gælder det om at opnå størst muligt overblik med færrest mulige menneskelige ressourcer. Samtidig opnås den mest effektive straf med mindst mulig lidelse, da udviklingen fra pinestraf til systematisk indespærring må betegnes som et humanistisk fremskridt i straffehistorien. ${ }^{2}$

I dag kender vi primært Benthams panoptikon i Michael Foucaults fortolkning. I bogen Surveiller et punir (1975, da. Overvågning og straf, 2002) kortlægger Foucault strafferettens europæiske historie fra den middelalderlige pinestraf til den moderne tids fængselsstraf. Det er historien om udviklingen fra den offentlige, spektakulære og øjeblikkelige afstraffelse eksempelvis i form af afhuggelse af lemmer til tidsbestemt indespærring, hvor forbryderne gemmes væk i fængsler. Foucault beskriver panoptismen som en ny politisk anatomi, hvor disciplinen erstatter en tidligere suveræn magt- 
instans (f.eks. kongen), der manifesterede sig i pomp og pragt. I stedet udøves magten på en mere skjult måde ved at objektivere og skabe viden om dem, der skal kontrolleres. Panoptismen er altså en disciplinerende magt, der vil dressere og manipulere kroppen, og panoptismen har derfor både en negativ funktion, der virker afgrænsende, og en positiv funktion, som er produktiv. På hospitalet giver den disciplinerende magt sig til kende på mange måder, idet afgrænsninger og regler er nødvendige for at producere sundhed tilsvarende fængslernes produktion af lovlydighed, skolernes produktion af vidende elever og hærens produktion af ødelæggelseskraft. Disciplinens midler er eksercits, optegnelser, rapportering, inddeling, undersøgelse, regulering og ikke mindst overvågning, som spiller en central rolle som en slags «synliggørelsesinstrument», der sikrer kontrol af det enkelte menneske. Disciplinens magtudøvelse sker således væsentligst gennem blikket, nærmere bestemt det altoverskuende øje.

Disse to emner tanken om en uhyggelig storebror og en plantegning af et fængsel har altså stået som centrale referencepunkter indenfor overvågningsforskningen og i den offentlige debat. Det kan derfor ikke undre, at overvågningens mere bekymrende sider har fyldt godt i litteraturen og debatten. Ofte er overvågningspraksisser og -teknologier blevet forstået som undertrykkende, ubehagelige og måske ligefrem nedbrydende. En grundtanke er her, at overvågning er en måde, hvorpå man udøver magt med særligt fokus på at kontrollere andre. Indenfor særligt den sociologiske tradition for overvågningsforskning har magtbegrebet spillet en stor rolle, dels med udgangspunkt i Foucaults tænkning, og dels med sociologen James Rules bog Privat lives and public surveillance (1973), der i øvrigt blev udgivet to år før Foucaults indflydelsesrige værk. Rules bog, der ikke er nær så kendt som Foucaults, har med sit fokus på sociale forandringer snarere end privatlivets fred været en tydelig inspirationskilde for eksempelvis David Lyon, som må regnes blandt de mest toneangivende overvågningsforskere de seneste femten år. Lyon har særligt med bøgerne Surveillance society (2001) og Surveillance studies (2007) markeret sig som en central skikkelse indenfor dette forskningsområde, hvor overvågningens samfundsmæssige aspekter underkastes et kritisk blik.

\section{Sociale fællesskaber på nettet}

I de senere år har sociale fællesskaber forandret sig fra at være undergrundskultur til at være hovedaktiviteten på internettet (Lenhart \& Madden 2007). Det er ikke længere blot entusiaster, der udveksler tekstbeskeder i simple nyhedsgrupper; nu tilbyder en lang række websider og tjenester at danne rammen om forskellige former for social interaktion mellem eksempelvis kolleger, familie, skolekammerater og helt fremmede. Disse tjenester 
indeholder som regel profiler, samt muligheden for at knytte forbindelser til andre brugere, ligesom der ofte er mulighed for forskellige former for kommunikation og udvekslinger (boyd \& Ellison 2007).

Der er mange eksempler på sådanne sociale fællesskaber på nettet, og de har ofte rod i web 2.0-tjenester eller -hjemmesider. En lang række forskelligartede tjenester tilbyder måder at kommunikere, informere og ikke mindst at socialisere. Det kan være i form af en bloggingsoftware (f.eks. Wordpress og Blogger), hvor en eller flere forfattere deler tanker om forskelligartede emner, lige fra det meget private til det det rent arbejdsmæssige eller faglige (Rettberg 2008), og det kan være i form af «tweets», det vil sige korte beskeder, som faciliteres af den populære tjeneste Twitter. Ligeledes kan man med tjenester som del.icio.us, furl og digg dele internetbogmærker og dermed vise, hvilke «input» man for tiden er udsat for. Med tjenester som Last.fm er det muligt at vise andre, hvilken musik, der lyttes til netop nu, og med tjenester som Foursquare og Google Latitude kan man vise, hvor man præcis befinder sig geografisk. Endelig er tjenesten Facebook, der samler og dyrker alle disse muligheder, en central del af social interaktion på nettet $\mathrm{i}$ dag.

Når disse ellers adskilte strømme af informationer løber sammen, danner de et nuanceret billede af brugerprofilerne. Det har ført til en række bekymringer angående eventuelle krænkelser af brugernes privatliv, ligesom problemstillinger omkring social udstødelse, diskrimination og forringede jobmuligheder har været nævnt både i den offentlige debat og i forskningslitteraturen (Tribble 2005). Som en del af denne debat har været et fokus på at oplyse og opdrage især unge om deres adfærd i forbindelse med sociale fællesskaber på nettet. Argumentet er, at siden brugerne tilsyneladende ikke forstår hverken de kortsigtede eller langsigtede konsekvenser af sociale interaktioner på nettet, så er det nødvendigt at sætte ind med informationer og vejledning om disse emner.

Det er altså en udbredt opfattelse, at sociale fællesskaber på nettet kan udgøre en fare for de mennesker, der tager del i dem. Denne frygt kan henføres til nogle af de særlige kendetegn, der gør sig gældende ved netbaserede fællesskaber, og her har den amerikanske forsker danah boyd foreslået fire interessante træk. Ifølge boyd (2007) er sociale fællesskaber på nettet kendetegnet ved, at de er blivende (persistency), søgbare (searchability), kan kopieres (replicability) samt have et skjult publikum (invisible audiences).

Sociale fællesskaber på nettet har en særlig blivende karakter, eftersom den sociale kommunikation og de andre genererede informationer gemmes på servere i et ukendt tidsrum. Konsekvensen af det er selvfølgelig, at hvad folk blogger om, herunder kommentarer til blogposter, samt anden tilsyneladende øjeblikkelig og situationsbaseret kommunikation vil være tilgængelig på et senere tidspunkt og i måske helt andre sammenhænge. Eksempelvis kan ungdommelige udskejelser på nettet måske dukke op, når en mulig arbejdsgiver googler navnet på en ansøger, der således stilles i en pin- 
lig og måske karriereskadelig position. Det er i hvert fald det, som skeptikere frygter.

Det andet kendetegn er søgbarhed, og det gør informationer væsentligt lettere tilgængelige. Blot ved at indtaste et par målrettede søgeord, præsenteres de informationer, der ledes efter, i prioriteret rækkefølge i forhold til søgningen, og dermed overflødiggøres tidskrævende indsamling og sortering. Denne tilnærmelsesvis øjeblikkelige adgang til det, der søges efter, forandrer tilgængeligheden sammenlignet med den langsommelige proces, hvor informationer manuelt skal "graves» frem.

For det tredje kan de sociale fællesskaber på nettet kopieres og reproduceres i mange forskellige sammenhænge qua deres digitale beskaffenhed. Ligesom med andre former for digital information kan social kommunikation på nettet løsrives fra det specifikke medie og endda ændres, før det reproduceres og distribueres i helt andre sammenhænge.

Det fjerde og sidste kendetegn, som danah boyd peger på, er det usynlige publikum, sociale fællesskaber på nettet kan have. Det er ofte sådan, at brugerne kommunikerer med et bestemt publikum i tankerne, f.eks. deres venner, men de sociale fællesskaber er i mange tilfælde mere eller mindre synlige for alle med adgang til de specifikke websider, f.eks. Facebook, MySpace eller danske Arto. ${ }^{3}$ Dermed bliver den sociale information tilgængelig for et stort publikum i princippet alle med internetadgang.

Tilsammen gør disse fire træk, at de sociale relationer på nettet har en blivende karakter, der rækker ud over de involverede personers kontrol. Dermed bliver social interaktion, der sædvanligvis opfattes som noget nærværende og knyttet til bestemte situationer, forandret til det modsatte, det vil sige asynkrone og offentlige relationer. Sagt på en anden måde, så bliver det, der tænkes som nærværende, til et stadigt potentiale for fremtiden.

\section{Snushanernes onskedrom}

Sociale fællesskaber er i høj grad baseret på hverdagslivets sprog og situationer, og de står derfor for noget, der i udgangspunktet hører privatlivet til. Disse private sociale interaktioner foregår imidlertid på nettet, der er tilgængeligt for et større publikum, som det fremgår af det ovenstående. Dette dilemma er selvfølgelig centralt for diskussionen af overvågning og privatlivets fred i forbindelse med sociale fællesskaber på nettet, særligt i forbindelse med sekundære anvendelsesmuligheder af de mange informationer.

Det er bredt accepteret, at terrorangrebene den 11. september 2001 har ført til skærpet og måske fremskyndet overvågning i statslig regi, særligt i USA og mange europæiske lande (Lyon 2003). Denne interesse retter sig også mod sociale fællesskaber på nettet. Tilsyneladende støtter en af de amerikanske efterretningstjenester, NSA (National Security Agency), fors- 
kning i og udvikling af metoder til systematisk at «høste» de mange informationer, der deles i forbindelse med sociale fællesskaber på nettet (Marks 2006).

Det er ikke svært at forstå, hvorfor myndighederne kan have en sådan interesse i sociale fællesskaber på nettet. For at kunne profilere og dermed identificere kriminelle og potentielle terrorister, er det en stor fordel at kunne sammenkøre mange typer af informationer. Det kan eksempelvis være informationer angående sociale relationer, herunder delte interesser og aktiviteter, omgangskreds, samt personlige oplysninger om politiske overbevisninger, religiøse tilhørsforhold, seksuel orientering og en lang række af andre præferencer, holdninger og vaner.

Det er netop informationer som disse, der gøres tilgængelige i forbindelse med sociale fællesskaber på nettet. De fleste tjenester, som faciliterer sociale fællesskaber på nettet, beder deres brugere om at dele netop sådanne oplysninger, ligesom den slags informationer deles i forbindelse med hverdagens kommunikation mellem brugerne. Dermed er de informationer til rådighed, der skal til for at profilere folk, tilmed uden brug af avancerede overvågningsteknologier, agenter og andet udstyr, der kan være som taget ud af en spionroman. Det er brugerne selv, som publicerer disse informationer, der i mange tilfælde er frit tilgængelige og nemme at indsamle. Således er sociale fællesskaber på nettet med god grund blevet kaldt for «snushanernes ønskedrøm» («a snoop’s dream») (Marks, 2006).

Man kan udtrykke det på den måde, at det blot er et spørgsmål om at forbinde de løse ender. Personfølsomme informationer er tilgængelige og kan kombineres fra flere forskellige kilder på en måde, hvor helheden kan give mere mening end de enkelte dele. For at illustrere denne situation kan vi bruge David Lyons begreb om «utætte beholdere» («leaky containers») (Lyon 2001:37-48). Lyon bruger dette begreb til at beskrive, hvordan informationer flyder frit mellem forskellige sektorer i samfundet. Resultatet er, at oplysninger fra adskilte kontekster, f.eks. privatliv, arbejdsliv og forbrug, flyder sammen i stedet for at forblive adskilte informationer.

Vi kan finde eksempler i mange sammenhænge, men et tankevækkende et af slagsen er et sammenfald af politiarbejde og sociale fællesskaber på nettet. Ifølge en historie i medierne (Maxcer 2007) har politiet i Canada og USA brugt videodelingstjenesten YouTube i deres efterforskningsarbejde. Ved at postere klip optaget med overvågningskameraer, der viser forbrydere i færd med at begå kriminalitet, forsøger politiet at indhente oplysninger fra befolkningen på en måde, der drager fordel af de nye mediers muligheder. At politiet bruger sociale fællesskaber på nettet i dette tilfælde en videodelingstjeneste er et eksempel på utætte beholdere, eftersom det offentlige og det private, det formelle og det sociale, blandes på helt nye måder. Social interaktion bliver et redskab for politiet, ligesom politiets efterforskning bliver en del af den sociale interaktion. 


\section{Deltagende overvågning}

Sociale fællesskaber på nettet implicerer adskillige problemstillinger, hvor forskellige praksisser for overvågning kan vise sig etisk uforsvarlige. Det er klart, at sådanne sammenhænge må undgås, og at en vigtig opgave består i at identificere og forebygge uhensigtsmæssige måder at overvåge. Denne vigtige opgave skal imidlertid ikke overskygge andre mere positive eller opbyggelige overvågningspraksisser, som vi møder på nettet. Her indgår overvågning som en del af en praksis af sociale interaktioner, hvor brugerne dels formidler informationer om sig selv, og dels følger med i andres aktiviteter. Denne måde at forholde sig på i forbindelse med overvågning er svær at forklare ud fra gængse overvågningsbegreber som f.eks. panoptisme. I det følgende vil jeg stille skarpt på disse aspekter og introducere begrebet «deltagende overvågning» («participatory surveillance» ${ }^{4}$ ). I den forbindelse vil jeg særligt fokusere på fire emner: synlighed, deltagelse, magt og gensidighed.

\section{Synlighed}

Synlighed er et centralt emne i denne sammenhæng, da den visuelle metafor som bekendt indgår i ordet «overvågning». Ofte udlægges overvågning som en hierarkisk praksis med henvisning til ordets etymologi. Ordet kommer af det franske "surveiller», der kan oversættes til "våge over» eller det mere brugte «overvåge». Det franske ord leder tanken hen på en situation, hvor en person er placeret over en anden og bruger denne position til at holde øje. Tanken er, at en sådan hævet position giver overblik og bedre udsyn, og placeringen er dermed gunstig. Denne visuelle metafor ligger til grund for udlægningen af overvågning som en magtrelation, hvor overvågeren kontrollerer den overvågede. Synlighed bliver dermed en svaghed; den, der kan ses, er samtidig sårbar for et kontrollerende blik.

Denne forståelse af overvågning som en hierarkisk magtrelation er udbredt såvel i hverdagsbrug som i den offentlige og den akademiske debat og i kulturelle sammenhænge. I denne artikel argumenterer jeg for, at vi med fordel kan se med nye øjne på disse relationer, men først er det hensigtsmæssigt at uddybe tanken om synlighed som en svaghed. Det væsentligste eksempel er formentlig Orwells beskrivelse af et overvågningssamfund, hvor borgernes komplette synlighed er et vigtigt element Her er synligheden et værktøj for staten personificeret ved Big Brother til at nedbryde det enkelte individ for derefter at kunne opbygge en mønsterborger. Denne formynderiske vision har træk tilfælles med Benthams ide om et Panoptikon, hvor fangerne (eller arbejderne, eleverne, soldaterne...) disciplineres. Her fungerer synligheden som et vigtigt instrument $\mathrm{i}$ forbindelse med den individuelle afretning. 
Denne ide om synlighed som noget, der kan bruges til at nedbryde, kontrollere og eventuelt genopbygge er velkendt fra romaner, film og computerspil (Albrechtslund 2008). Ligeledes er overvågning ikke blot et flittigt brugt tema i fiktionens verden, det er også et vigtigt aspekt ved den måde, som historier fortælles på. I de senere år har vi set en række eksempler på, at hollywoodfilm har indlemmet tv-overvågning som en del af filmenes æstetik, og det kan for eksempel være på den måde, at der klippes til billeder fra tv-overvågningskameraer. Disse billeders ofte uklare og lidt distancerede karakter bliver således en del af æstetikken og den narrative struktur (Kammerer 2004; Levin 2002). Et eksempel, der illustrerer denne tematiske og strukturelle rolle som overvågning spiller, er den amerikanske spændingsserie 24 timer (24, Fox News). Her fortælles historierne i et højt tempo, og plottet er ofte baseret på informationer, der indhentes ved hjælp af overvågning $\mathrm{i}$ realtid. De forskellige overvågningsteknologier og -prakssiser, der anvendes, er for eksempel GPS og indtrængning i databaser, ligesom billeder fra satellitter og tv-overvågning er integreret $i$ alle episoder. En karakteristisk måde, som handlingen udspiller sig på i 24 timer, er med computereksperten Chloe O'Brien (Mary Lynn Rajskub) siddende ved en computer, mens hun via headset er i kontakt med Jack Bauer (Kiefer Sutherland), seriens über-agent, mens han udfører en ofte vanskelig og farlig mission. Sådanne scener udspiller sig som regel på den måde, at Chloe hele tiden faciliterer Jacks handlinger ved at tilvejebringe relevante oplysninger ved hjælp af overvågning.

\section{Deltagelse}

Når vi reflekterer over deltagelse i forbindelse med overvågning, er det vigtigt at sondre mellem det, jeg her vil kalde «ægte» deltagelse, over for pseudo-deltagelse. For at der kan være tale om ægte deltagelse, kræver det et aspekt af frihed, hvorimod mere eller mindre tvungen deltagelse må klassificeres som pseudo-deltagelse. På samme måde som muligheden for et frit valg kræver, at den handlende person ikke er fuldstændigt underlagt tvang, så kræver den form for deltagelse, som vi her taler om, at personen som minimum har mulighed for at vælge $i k k e$ at deltage ${ }^{5}$ Det er vigtigt at præcisere, at ægte deltagelse ikke nødvendigvis er motiveret af personlige interesser eller ønsker. Når man eksempelvis tager aktivt del i nødhjælpsarbejde, så kan dette engagement naturligvis være givende i form af tanken om at «gøre en forskel», men det kan samtidig være ganske krævende og omkostningsfuldt for nødhjælpsarbejderen. På samme måde kan andre situationer, der relaterer til arbejde eller fritidsbeskæftigelser, have karakter af aktiv, frivillig deltagelse, men som ikke involverer en snæver personlig gevinst. 
Denne form for deltagelse må adskilles skarpt fra den deltagelse, som forekommer i forbindelse med Benthams panoptikon og det samfund, der beskrives i Orwells 1984. Her er deltagelsen kun tilsyneladende ægte. Et panoptikon er bygget op på en sådan måde, at fangerne (eller eleverne, arbejderne, soldaterne...) selv tager del i deres egen overvågning. Det sker på den måde, at overvågerens blik internaliseres af den, som bliver overvåget. På lignende måde i Orwells roman, hvor borgerne i Oceanien tager del i deres egen (og andres) overvågning som et led i deres «kærlighed» til Big Brother. I begge tilfælde pålægges overvågningen af noget udefrakommende, dels som fange i en magtrelation (Foucault 1975) eller som resultat af hjernevask udført af «Ministry of Love» (Orwell 1949).

Udover skellet mellem ægte deltagelse og pseudo-deltagelse, så er det hensigtsmæssigt at sondre mellem «aktiv» og «passiv» deltagelse, selvom disse niveauer i praksis ofte overlapper hinanden. Med passiv deltagelse tænker jeg på sammenhænge, som ikke umiddelbart falder under de former for pseudo-deltagelse, som beskrevet ovenfor, men hvor deltageren alligevel ikke kan siges at have truffet et aktivt valg. Sådanne sammenhænge indgår vi alle i, og et nærliggende eksempel er vores deltagelse i samfundet. Her deltager vi qua vores demokratiske rettigheder, ligesom vi er forpligtet af landets love, men der er langt fra tale om deltagelse i Orwells totalitære forstand. Man kan diskutere, hvorvidt deltagelse i samfundet har panoptiske træk, eftersom Foucault netop argumenterer for denne position i forbindelse med det moderne samfund (1975). Problemstillingen viser, at ligesom forholdet mellem aktiv og passiv deltagelse udgør pseudo-deltagelse og det, jeg her kalder passiv deltagelse, snarere et kontinuum end to skarpt afgrænsede enheder. Passiv deltagelse er altså karakteriseret ved, at vi mere eller mindre bevidst og frivilligt indgår i forskellige sammenhænge, der er præget af overlevering, for eksempel i form af politiske systemer eller andre traditioner. Vi er her deltagere i et «flow», uden aktivt at tage stilling til denne ramme for vores liv og handlinger. Anderledes tager det sig ud med aktiv deltagelse, der er kendetegnet ved en form for engagement, som går ud over det forhold, at man er situeret i tid og sted samt i kulturelle og sociale relationer. Der er altså tale om aktiv stillingtagen eller om situationer, hvor man selv gør noget for at deltage.

Når jeg taler om deltagende overvågning, så er der tale om det, jeg ovenfor kalder ægte, aktiv deltagelse, hvor synligheden som oftest vil opfattes som noget positivt. Der er naturligvis mange sammenhænge, hvor en sådan form for overvågning kan udfolde sig i praksis, ligesom der er en mangfoldigheder af måder, det kan ske på. Eksemplet, som jeg her fremhæver, er sociale fællesskaber på nettet, men i princippet kan deltagende overvågning være del af en bred vifte af forskelligartede praksisser. 


\section{Magt}

Som tidligere nævnt udtrykker en hierarkisk forståelse af overvågning ofte en magtrelation, som favoriserer den person, der udfører overvågningen og reducerer den person, som er under overvågning til et magtesløst, passivt subjekt, der kontrolleres af overvågerens blik. Når vi ser på sociale fællesskaber på nettet, så forekommer denne praksis ikke at kunne beskrives fyldestgørende ud fra en hierarkisk forståelse af overvågning. Her er det ikke sådan, at overvågningspraksisserne nedbryder de personer, der tager del i den. Hverken som overvågere, der følger andres informationsstrømme eller endnu vigtigere som overvåget, der selv bidrager væsentligt til disse informationsstrømme. Det er snarere sådan, at disse overvågningspraksisser er del af en «leg» med identiteter, som kan være med til at opbygge fremfor for at nedbryde subjektiviteten.

Et eksempel, der kan illustrere dette, er Hille Koskelas (2004) overvejelser angående brugen af webcam, tv-serier og mobiltelefoner. Hun introducerer begrebet «magtgivende ekshibitionisme» («empowering exhibitionism») til at beskrive en praksis, hvor man deler ganske intime detaljer fra sit privatliv. Koskela argumenterer, at de deltagende personer så at sige gør krav på deres eget liv ved at engagere sig i denne ekshibitionistiske konstruktion af deres eget liv (Koskela 2004: 206). Denne måde at forstå overvågning på er med til at forandre den hierarkiske, vertikale overvågningsrelation til et gensidigt, horisontalt forhold mellem mere ligeværdige aktører. Her bliver synlighed til et positivt værktøj, der kan bruges til at imødegå den mulige skam, der kan være associeret med ikke at holde visse dele af privatlivet for sig selv. Derfor kan ekshibitionisme være en form for frigørelse, da det udtrykker en praktisk afvisning af at være ydmyg (Koskela 2004: 210).

\section{Gensidighed}

Som diskussionen om magt ovenfor viser, kan den hierarkiske forståelse af overvågning ikke alene på fyldestgørende vis forklare overvågningens karakter. Det etymologiske udgangspunkt, hvor overvågerens blik fastholder den overvågede i et kontrollerende greb, synes ikke at kunne indfange alle overvågningssituationer, særligt ikke de praksisser vi finder i forbindelse med sociale fællesskaber på nettet. Her er der snarere tale om en «flad» relation, hvor den overvågede ikke er fanget af overvågerens blik, men i stedet for bliver en aktør med egen dagsorden. Det kan eksempelvis være i form af modstand mod overvågerens blik (Ball \& Wilson 2000; McGrath 2004), eller, som vi så ovenfor, kan det komme til udtryk på en mere positiv måde i form af «magtgivende ekshibitionisme» (Koskela 2004).

Fælles for disse alternative måder at beskrive overvågning er et fokus på gensidighed. Ligeledes er den overvågedes modstand mod overvågerens 
blik og den overvågedes dyrkelse af synlighed udtryk for et skift fra passiv til aktiv. Den overvågede er ikke et passivt offer for overvågerens blik, men en aktiv part i relation, men denne gensidighed er dog ikke nødvendigvis frigørende. Mark Andrejevic (2005) har beskrevet den som en form for «lateral overvågning» («lateral surveillance»), det vil sige en praksis, hvor overvågningen er spundet ind i mange af hverdagens gøremål. Der er altså tale om en individuel aktivitet, hvor almindelige mennesker bruger overvågningspraksisser og -teknologier til at holde øje med kærester, familie og venner (Andrejevic 2005: 488). Overvågningen er her ikke noget, som er begrænset til at udgå fra staten eller virksomheder, men noget som vi alle kan give os i kast med. Her er overvågningen ikke noget ekstraordinært, snarere noget almindeligt som vi alle tager del i.

Andrejevics pointe er, at vi dermed alle bliver spioner i det fængselsagtige samfund som vi kender fra Foucault. Det er de panoptiske principper,

der har spredt sig fra fængslets gange til samfundets principper og ifølge Andrejevic videre til almindelig menneskers hverdagsliv. En konsekvens af denne forskydning er, at der ikke længere er vandtætte skotter mellem politi- og spionteknologier og sociale teknologier. Andrejevic (2005: 8) påpeger, at der nu er et tankevækkende sammenfald mellem de teknologier og praksisser som efterretningstjenester bruger, og dem som bruges i forbindelse med dating, børneopdragelse og almindelig social interaktion mellem venner og bekendte.

Lateral overvågning er et interessant og tankevækkende begreb, men det kan efter min vurdering ikke på en tilstrækkelig måde give os en forståelse af sociale fællesskaber på nettet, som beskrevet ovenfor. Begrebet fastholder grundelementerne fra den panoptiske ide, hvor det disciplinære samfund blot har udviklet sig til et spionsamfund. Omvendt er ideen om overvågning som en gensidig praksis værd at holde fast $i$, da det element svarer ganske godt til nogle af de overvågningspraksisser, som jeg har været inde på tidligere. Når vi ser på sociale fællesskaber på nettet, er der altså ofte tale om en struktur, hvor overvågningen går begge veje, og en sådan relation er derfor horisontal snarere end vertikal.

\section{Konklusion}

Min ambition med denne artikel er ikke at erstatte andre forståelser af overvågning, endsige at insistere på en udtømmende forståelse af de overvågningsteknologier og -praksisser, der har at gøre med sociale fællesskaber på nettet. Mit håb er at bidrage dels til overvågningsdiskussionen og dels til forståelsen af sociale fællesskaber ved at sætte fokus på elementer, der kan være gensidigt belysende. 
At dele personlige informationer med andre - ofte et større publikum end blot nære venner - er en type kommunikation, som vi ikke skal reducere til skræmmende overvågningsscenarier eller til simple byttehandler, hvor man giver lidt af sig selv for at få noget at vide om andre. Selve delingen af information profiler, aktiviteter, tro, opholdssted, status, præferencer, osv. er kommunikation på et niveau, hvor der ikke nødvendigvis er behov for spørgsmål eller svar. At disse informationer deles i en social overvågningspraksis er en del af det grundlag, som netbaserede fællesskaber er bygget på. Det understreger behovet for et pluralistisk begreb om overvågning, hvor sociale praksisser, leg og underholdning fyldestgørende kan beskrives som de overvågningspraksisser, de også er.

Begrebet deltagende overvågning kan bruges til at fremhæve brugernes motiver for at dele informationer, og begrebet giver mulighed for at forstå denne praksis som noget produktivt. Synlighed er ikke nødvendigvis det samme som at være sårbar, og her kan en nytænkning af overvågningsbegrebet tilbyde andre perspektiver på sociale fællesskaber på nettet.

\section{Noter}

1 Jeg bruger i artiklen «fællesskaber» som en overgribende term, der dækker over alle de forskellige praksisser og relationer, vi udfolder på de sociale medier. «Fællesskab» skal altså ikke forstås i snæver forstand eller som en modsætning til «netværk», hvilket nogle gange ses indenfor internetforskningen.

2 Jeg vil dog her minde om, at Foucault rent faktisk ikke ser denne udvikling i straffehistorien som noget særligt humanistisk fremskridt (1975). Der er blot tale om forandringer i samfundets strukturer og i magtudfoldelsen.

3 Diskussioner om brugernes privatliv i forbindelse med disse sites har raset i de senere år. En konsekvens af denne debat er, at brugerne i dag har forholdsvis stor kontrol med, hvilke informationer, der deles med hvem. Eksempelvis er Facebookprofiler ikke åbne for alle brugere, med mindre man selv vælger det, ligesom de mange informationer ikke dukker om i f.eks. Googles søgeresultater.

4 Begrebet "participatory surveillance» er udviklet og nærmere beskrevet i min ph.d.afhandling In the Eyes of the Beholder: Introducing participation and ethics to surveillance, Aaalborg Universitet (2008).

5 Det er klart, at fuldstændig betingelsesløs frihed næppe er en praktisk mulighed, da alle frie valg må træffes i konkrete situationer. Det vil sige, at en række forhold, forventninger, særlige omstændigheder osv. må medtænkes og vægtes. Ligeledes vil ægte deltagelse som oftest være motiveret af andre forhold, forventninger, særlige omstændigheder osv. 


\section{Litteratur}

Albrechtslund, A. (2008) Surveillance and ethics in film: Rear window and the conversation. Journal of Criminal Justice and Popular Culture, 15 (2), s. 129-144.

Andrejevic, M. (2005) The work of watching one another: Lateral surveillance, risk, and governance. Surveillance \& Society, 2 (4), s. 479-497.

Ball, K. \& Wilson, D.C. (2000). Power, control and computer-based performance monitoring: Repertoires, resistance, and subjectivities. Organization Studies, 21 (3), s. 539-565.

boyd, d. (2007) Social network sites: Public, private, or what? The Knowledge Tree, 13 (May). Hentet 30. juni, 2010 fra http://kt.flexiblelearning.net.au/tkt2007/ ?page_id $=28$

boyd, d. \& Ellison, N. (2007) Social network sites: Definition, history, and scholarship [Electronic Version]. Journal of Computer-Mediated Communication, 13. Hentet 30. juni, 2010 fra http://jcmc.indiana.edu/vol13/issue1/ boyd.ellison.html

Foucault, M. (1975) Surveiller et punir: Naissance de la prison. Paris: Gallimard.

Kammerer, D. (2004) Video surveillance in Hollywood movies. Surveillance \& Society, 2 (2-3), s. 464-473.

Koskela, H. (2004) Webcams, TV shows and mobile phones: Empowering exhibitionism. Surveillance \& Society, 2 (2-3), s. 199-215.

Lenhart, A. \& Madden, M. (2007) Teens, privacy \& online social networks. Washington, DC: PEW Internet \& American Life Projecto.

Levin, C.T.Y. (2002) Rhetoric of the temporal index: Surveillant narration and the cinema of «real time». In CTRL [Space]. Rhetorics of surveillance from Bentham to Big Brother, red. T.Y. Levin, U. Frohne \& P. Weibel, s. 578-593. Cambridge, MA: MIT Press.

Lyon, D. (2001) Surveillance society. Buckingham: Open University.

Lyon, D. (2003) Surveillance after September 11. Malden, MA: Polity Press, in association with Blackwell.

Lyon, D. (2007) Surveillance studies: An overview. Cambridge, UK \& Malden, MA: Polity Press.

Marks, P. (2006) Pentagon sets its sights on social networking websites. NewScientist.com. Hentet 30. juni, 2010 fra http://www.newscientist.com/article/mg19 025556.200

Maxcer, C. (2007, March 6) Cops Nab Crooks Using YouTube. TechNewsWorld. Hentet 30. juni, 2010 fra http://www.technewsworld.com/story/56 108.html

McGrath, J.E. (2004) Loving big brother: Performance, privacy and surveillance space. London \& New York: Routledge.

Orwell, G. (1949) Nineteen eighty-four, a novel. London: Secker \& Warburg.

Rettberg, J. (2008) Blogging. Cambridge, UK \& Malden, MA, USA: Polity Press.

Rule, J. B. (1973) Private lives and public surveillance. London: Allen Lane.

Tribble, I. (2005) Bloggers Need Not Apply. Hentet 30. juni, 2010 fra http://chronicle.com/jobs/2005/07/2 005070 801c.htm 